\title{
Bamboo Material Benefits in Lobby Eco Villa Construction Building in Mandalika Area, Lombok-Nusa Tenggara Barat
}

\author{
Komang Micho Wedayana ${ }^{1}$, I Gusti Ngurah Anom Rajendra ${ }^{2}$, Ni Ketut Agusintadewi ${ }^{3}$ \\ Bachelor Degree of Architecture Study Program \\ Faculty of Engineering-Udayana University \\ Jimbaran \\ komangmicho@gmail.com \\ Architecture Study Program \\ Faculty of Engineering-Udayana University \\ Jimbaran \\ Architecture Study Program \\ Faculty of Engineering-Udayana University \\ Jimbaran
}

\begin{abstract}
Bamboo is one of the building materials that is no stranger to the people of Indonesia. Bamboo grows abundantly throughout Indonesia and has become part of the lives of Indonesian people. Bamboo is used because it has strong material characteristics but has a light weight for building construction needs. Bamboo is also known to have ecological value that is good for the environment because it only takes about 3 to 5 years of growth to be ready for use as material better than wood materials that can reach 40 years. With very fast growth and the ability to adapt to a good climate, bamboo is an alternative material that can be a renewable resources. However, modern society now has a perception that bamboo is an ancient material and material for the poor and has a low aspect of durability. Even though bamboo can be used for the structure of tourism accommodation building as well as villa it will give a unique look with renewal of designs and the development of more innovative ways of preservation in order to become a development effort that is more directed towards environmental preservation. By using bamboo extensively in the structure of buildings, the circulation of the presence of bamboo can support the people's economy and have a great positive impact on the environment.
\end{abstract}

Index Terms - bamboo, building construction, renewable resousces, design.

\section{INTRODUCTION}

Bamboo is a plant that grows abundantly throughout the world. This plant has 1250-1500 species, while in Indonesia there are about 154 types of bamboo [1]. Bamboo is spread all over the Indonesian Archipelago and has been a part of people's lives for centuries. Indonesian people have long used bamboo for home construction, furniture, crafts, and even as food. Because it only takes 3-4 years to be ready to be used as materials and the regeneration process is considered fast, making bamboo can be classified as a sustainable natural resource. Bamboo has a tensile strength equivalent to steel and compressive strength that can be equivalent to concrete and has a high humidity moment. Therefore, bamboo is good enough to bear the bending moment, so that bamboo is the best alternative for solving building problems in earthquake-prone areas [2]. But bamboo has a low durability. Bamboo is very potentially attacked by pests, so that bamboo material has a short service life. Properly preserving techniques can extend the life span of bamboo. Bamboo material can last up to 50 years if bamboo has been preserved with modern techniques.

In Lombok, the use of bamboo as a building construction material has been done for centuries. Sade Village, for example, still uses bamboo as the main construction material 
for their traditional houses. Bamboo is used as a construction material for roofs and walls of bale-farm houses. Utilization of bamboo is not yet optimal because there is no preservation process that makes bamboo more durable, so it must be replaced periodically. In addition, the jointing technique must be carried out correctly in order to be a strong structure. Bamboo connection techniques are very diverse ranging from traditional connection techniques to modern connection techniques. The bamboo connection technique used in traditional villages in Lombok is still classified as very traditional, while technological advances have enabled bamboo construction to be stronger and more durable.

Utilization of bamboo in the design of eco villas in the Mandalika area is an interesting thing. To characterize the local wisdom of Lombok and prioritize ecological concepts in its development. Thus, the selection of bamboo material in the construction of lobby buildings is expected to be a design idea that is concerned with environmental aspects. The use of bamboo material in the construction field can also utilize less productive land for planting bamboo and can support local communities.

\section{RESUlt AND ANALISYS}

\section{A. Bamboo for Materials at the Lobby}

The lobby is a very important building in tourist accommodation. The lobby becomes a reception room, so visitors' comfort in the building is something to consider. To give an attractive first impression, the lobby is designed to give the local characteristics of Lombok with an attractive appearance on the exterior and interior. In the design of eco villas, the lobby is designed to interpret the Sasak Tribe's form of rice granary as a reference to the general form of the lobby building.

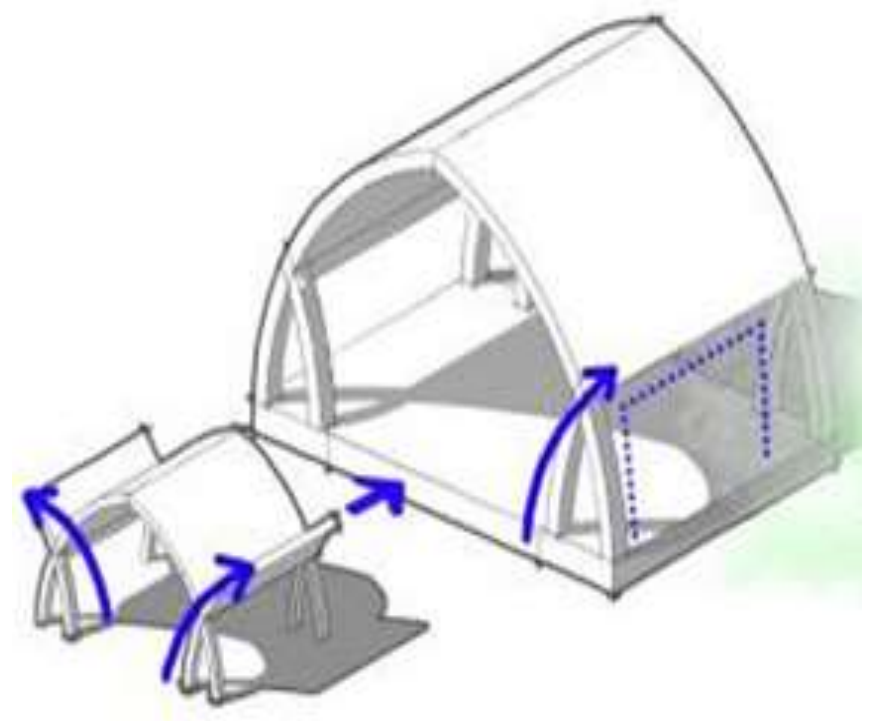

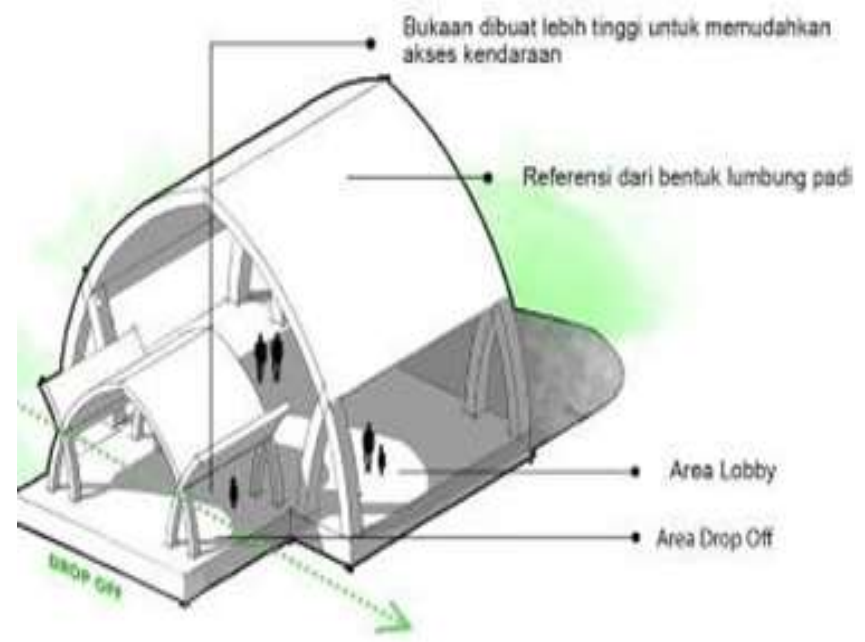

Fig. 1. Shape Transformation (source: Wedayana)

The shape of the lobby building is the union between two forms of modified Sasak Tribe granary, so that the appearance of the building consists of only two parts: the lower structure (floor) and the upper structure (roof). The drop off area has the same construction form as the lobby area, only distinguished by the dimensions of the building which is influenced by the need for spatial area (Figure 1). To make an ideal shape, bamboo is used as a construction material because bamboo has good elasticity to produce more dynamic shapes. Super structure construction using entirely bamboo material. The type of bamboo chosen is petung bamboo which has a larger diameter than other types of bamboo, with a diameter reaching $20-25 \mathrm{~cm}$ and a stronger endurance to accept the load. The structure of bamboo in each column has the same shape. To withstand horizontal forces, each bamboo structure is given a wind cross so that the entire structure becomes a solid and rigid whole. Unlike the bamboo structure in a more complex lobby area, the drop-off area uses a simpler structure. Figure 2 shows the structure of bamboo supported by local foundations at each point. It aims to minimize the shift caused by the tensile force of the bamboo when it is arched.

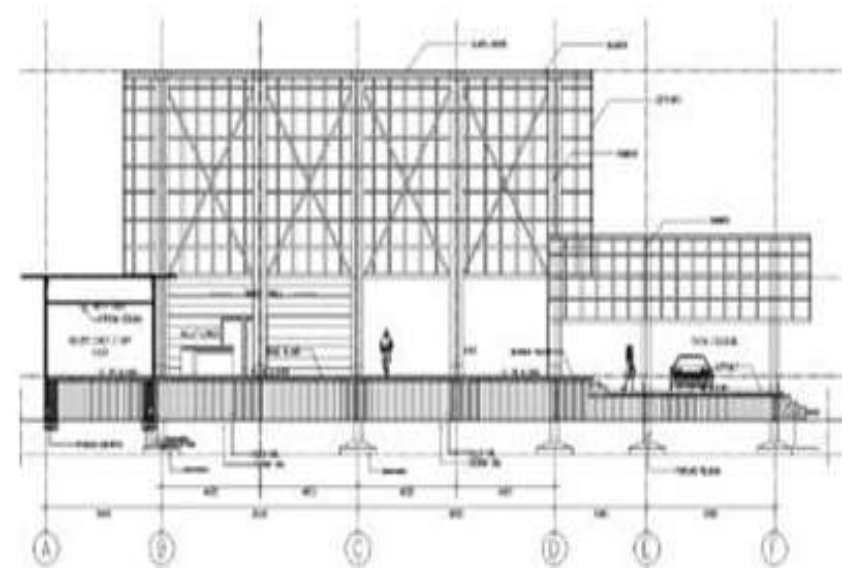




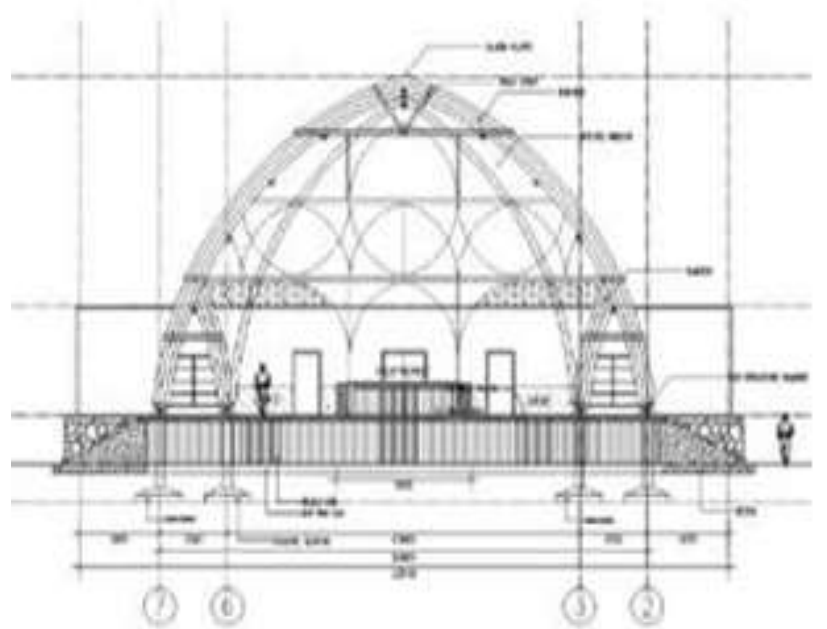

Fig. 2. Section A-A and B-B (source: Wedayana)

The construction of the lobby building consists of five main structures with a span of 18 meters long and 11 meters high. Each structure is 4.5 meters apart and integrated with the placement of bamboo vertically. The wide span of building and the curved shape causes bamboo material to be very suitable for building structures. Bamboo structure has strength beyond concrete. Bamboo is a lightweight lightweight material that is hollow, so that it can strengthen structures with light and not rigid loads (Frick, 2004). The nature of bamboo that is not rigid can be an advantage of bamboo in minimizing the impact caused by earthquakes. Thus, for wide-span building construction, the use of bamboo is very safe with the application of more modern connections (Sarlono, 1975). The lightweight nature of bamboo certainly impacts when there is wind movement. This can be overcome by crossing the placement of each major structure.

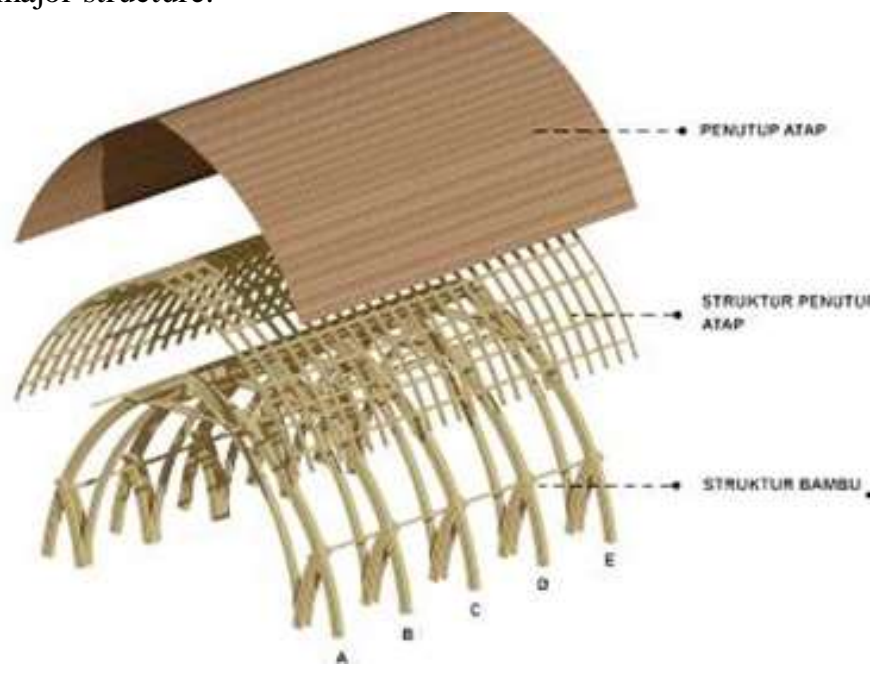

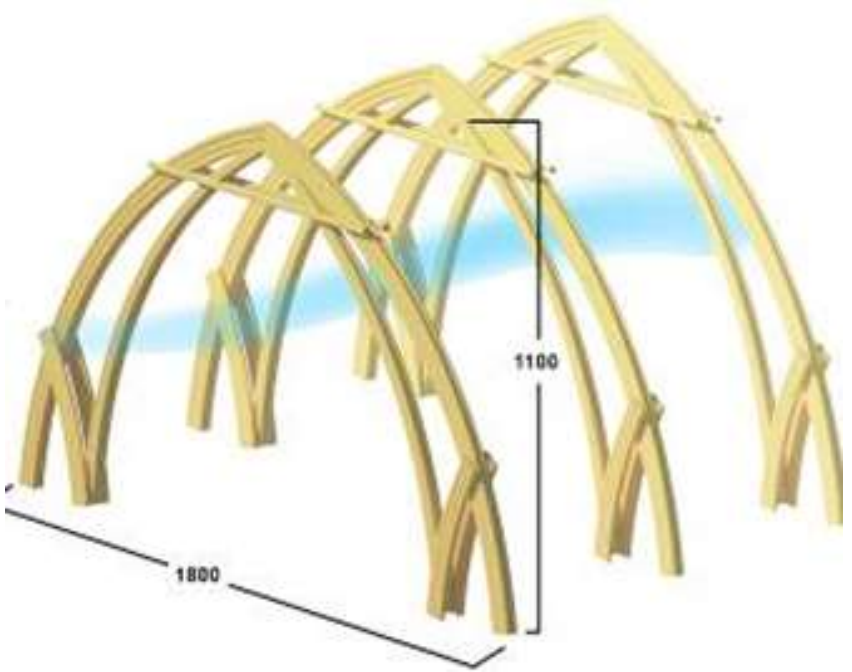

Fig. 3. Schematic Detail of Structure (source: Wedayana)

Bamboo is the fastest growing plant and produces 30\% more than wood forests in the same area because bamboo produces more biomass [1]. Therefore, bamboo qualifies as an environmentally friendly building material. The use of bamboo as a construction is one of the campaigns of sustainable development promoted by world architects. It only takes 3-5 years to be harvested, so the use of bamboo can have a positive impact on the environment because it reduces the use of wood and deforestation.

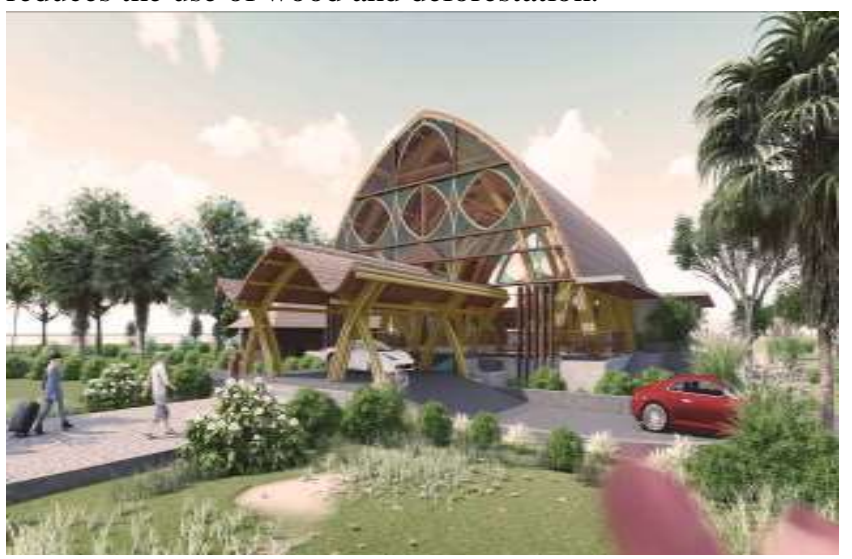

Fig. 4. Model (source: Wedayana)

The use of bamboo structures also makes the building look more attractive, both exterior and interior. The exposed bamboo structure is the main attraction to give a strong and dynamic impression. In addition, the appearance of the building becomes more in harmony with the environment. The elastic nature and can adjust to the vibrations that occur during an earthquake, causing bamboo is very well used in buildings in earthquake prone areas.

\section{CONCLUSION}

Eco villas in the Mandalika Region, Central Lombok are tourist accommodations that apply environmentally friendly principles. In the lobby, the building structure uses bamboo material to show the local identity of Lombok, which for centuries has used the material as an alternative building material. The use of bamboo structures gives freedom in 
determining the shape of the building, because of the nature of bamboo which is flexible, but has strong durability. In the lobby design, the shape of the Sasak rice barn is the basis for consideration in the selection of shapes. This is intended to give Lombok's identity the first time tourists enter the eco villa area which is also supported by its exterior and interior. In addition, the use of bamboo as a building material can be an effort to conserve the environment. It only takes 3-4 years for bamboo to be ready to be used as building material and a fast regeneration process, so that bamboo can be classified as a sustainable natural resource. Thus, the design will be in harmony with the surrounding environment and can be a real step in applying environmentally friendly architecture.

\section{REFERENCES}

[1] Widjaya, E.A, "Strategi Penelitian Bambu Indonesia", Yayasan Bambu Lingkungan Lestari. Bogor, 1994.

[2] Purwito, "The Application of Bambu for Earthquakes-resistant House", Proceedings of the Vth International Bambu Workshop and the IV International Bambu Congress, Bali, 19-22 June 1995, 1995.

[3] Darmasetiawan, Christian, Lestari Puspakesuma, "Teknik Pencahayaan dan Tata Letak Lampu Jilid 1 Pengetahuan Dasar", Jakarta: PT. Gramedia Widiasarana Indonesia, 1991. 